\title{
Impoliteness and Thematic Variation in Spanish Television Interviews
}

\author{
Ester Brenes Peña ${ }^{1}$, Catalina Fuentes Rodríguez ${ }^{2}$ \\ ${ }^{1}$ Facultad de Filosofía y Letras, Córdoba University, Spain \\ ${ }^{2}$ Facultad de Filología, Seville University, Spain \\ Correspondence: Ester Brenes Peña, Facultad de Filosofía y Letras, Universidad de Córdoba, Plaza del Cardenal 3, \\ 14071 Córdoba, Spain; Catalina Fuentes Rodríguez, Facultad de Filología, Universidad de Sevilla, c/Palos de la \\ Frontera s/n, 41004 Sevilla, Spain.
}

\author{
Received: October 29, 2015 \\ Accepted: March 26, 2017 \\ Online Published: April 5, 2017 \\ doi:10.11114/smc.v5i1.2332 \\ URL: https://doi.org/10.11114/smc.v5i1.2332
}

\begin{abstract}
This paper analyses Spanish television interviews and presents a contrast between the impolite argumentative strategies employed by the interviewer to attack the image of the interviewee in interviews with politicians and celebrities. It aims to demonstrate how the topic addressed and the subtype of interview influence the strategies employed and degree of impoliteness shown by the interviewer. The analysis of our corpus has shown that the current television interview differs from the traditional format of this genre in a number of respects. Impoliteness is used in Spanish interviews in order to attract the audience and to build the journalist's face in political interviews as participants in ideological confrontation. Nevertheless, the detailed study of the impoliteness strategies employed by the interviewer has shown that the modification of features largely depends on the subtype examined. We observed in television celebrity interviews a wider range of strategies of verbal impoliteness, which are absent from political interviews. This explains why a variationist perspective has been adopted in the analysis of verbal impoliteness.
\end{abstract}

Keywords: television discourse, Spanish television interviews, impoliteness, pragmatics

\section{Introduction}

This paper has a twofold aim: on the one hand, to show how verbal impoliteness is a defining factor in modifying televised interviews in Spain and, on the other, to determine whether the topic discussed affects the degree of verbal (im)politeness shown in these programs. The selected corpus comprises twenty television interviews: ten were conducted with important figures from the world of politics and the other ten with media celebrities ${ }^{1}$. This selection will allow us to compare different television interviews and, within them, to describe the influence exerted by the topic around which the interaction revolves, together with the register used.

Broadly, the article describes the range of impoliteness strategies used by the interviewer in Spanish television interviews and the functions that impoliteness may perform, establishing a contrast between political and celebrity interviews ${ }^{2}$. Our analysis is qualitative and located within the framework of variational pragmatics (Schneider \& Barron 2008). The results show that the principal aim of verbal impoliteness in the interviews analysed is to attract the audience's attention and to define the interviewer's identity. As a result, what was initially a genre based on the adjacent question-answer pair becomes a direct confrontation based on the adjacent assertion-rejection pair, where good manners are largely abandoned. This is the hibridity described by Ekstrom \& Patrona (2011). A similar shift has been detected in talk shows and reality television (Garcés-Conejos, Lorenzo-Dus, Bou-Franch, 2010; Brenes Peña, 2011). In interviews with politicians, however, the topic discussed, the status of the interviewee, and the register employed ensure that the level of impoliteness is lower than that of the celebrity interview.

Politeness theory provides the basis for the methodology adopted in this paper (Section 2). Previous studies on the television interview are presented in Section 3. Section 4 focuses on a characterization of the Spanish television interview and its essential features. A detailed description of the various impoliteness strategies deployed in interviews follows in Section 5. This is followed by an analysis, in section 6, of the functions or purposes for which impoliteness is used in these programs. Finally, Section 7 is dedicated to a discussion of the results obtained. 


\section{Methodology}

\subsection{Verbal (Im) Politeness from a Variationist Perspective}

At the outset, it is important to explain briefly what we mean by verbal (im) politeness. Our approach is based on a variationist conception of pragmatics (Schneider-Barron 2008, Fuentes Rodríguez 2013) whereby the assessment of a situation as polite or impolite is arrived at on the basis of the behaviour that is considered appropriate in a communicative situation (Locher and Watts 2005). This allows us to avoid both the two-way linguistic element-social effect association and ethnocentrism (Locher and Watts 2005, Fuentes Rodríguez 2010a, 2011, Brenes Peña 2011).

Our point of departure is the need to adopt a pragmatic perspective (Fuentes Rodríguez 2000) in which conditioning factors of the sociocultural milieu are combined with wider aspects based on the linguistic act as a communicative event. These are the discourse type or genre (Fuentes Rodríguez 2000, 2011), which are fundamental for studying the strategies the speaker employs to relate to the addressee. Similarly, the role of the participants in the act is a key factor in media discourse in order to determine the degree to which it corresponds to what is expected and conventionalized. It is a question therefore of a framework which connects with relational work theory (Locher-Watt 2005), according to which the sociohistorical and cultural context around the communicative event must be taken into consideration. Our approach likewise draws on argumentation theory since in our view (im)politenes is a strategy which the interviewer in this case employs to achieve his or her communicative ends ${ }^{3}$.

On this basis, then, each situation and genre includes a number of norms concerning what is expected, by which positive behavior (respecting the interlocutor's face) is assessed as polite whereas negative behavior (attacking the other's face) is considered impolite, generally by the ideal receiver. Both zones constitute a gradual continuum whose operation may be shown by means of syntactic, phonemic or semantic procedures:

+ +impolite -impolite -polite +polite

In this particular case, one of media discourse, the medium (television in this instance) is a relevant factor, since its aim - to attract and entertain viewers - will influence how the receiver will evaluate the impolite strategies employed. Our aim then is to establish whether or not this influences the evaluation of impoliteness.

In the specific case of TV interviews, a set of rules governs the interactive relationship between interviewer (IR) and interviewee (IE). These are the 'rules of the game' which create a framework of forces together with a hierarchy in interaction. A formal media-based discourse is created in which respect for the other's face is essential and the expected discursive uses are those associated with formality. Even so, accusations, especially if expressed aggressively, can strain the atmosphere. In this case, our aim is to demonstrate how these factors influence the course of the interview and the assessment of the interaction as polite or impolite.

This assessment should be complemented with other types of face-related operations (Holmes and Schnurr 2005, Spencer-Oatey 2007), and identity (Joseph 2004; Bucholtz and Hall 2005; Arundale 2010), which are essential in media discourse (Fuentes Rodríguez 2013). The participants in an interview do not jeopardize their personal face as individuals (labeled image 1 in Fuentes Rodríguez 2010b, 857). It is rather their role face, that of a professional or a public figure, which is important here (image 4). At the same time, they embody a group image (Bravo 2004), either that of the political party they represent if they are politicians, or that of their social or professional class, if they are celebrities from the world of music, theatre, etc. This representation of a group may be conscious (they may be acting as spokespersons) or an undesired extension of their professional identity ${ }^{4}$. At a particular stage of their careers, media professionals may opt to construct a distinct identity which allows them to stand out from their colleagues and rivals. Impoliteness is one of these features (Brenes Peña 2013a and b, Brenes-González 2013, González Sanz- Brenes Peña 2013, Fuentes Rodríguez 2016).

\subsection{Methodology and Corpus}

Operating with this conception of verbal (im) politeness, we have analyzed twenty televised interviews (ten with politicians and ten with celebrities), of nine hours' duration in total. The length was roughly the same, in order to be able to make the comparison but we were unable always to choose from the television schedules . The ten interviews with media celebrities were taken from the program 'La Noria' [The Ferris Wheel], broadcast every Saturday night on the private channel Tele5 since it is the only program that has interviews of this sort in the time-slot selected. The interviews with political figures, came predominantly from the breakfast show 'Los desayunos de TVE', broadcast daily on the Spanish public channel TVE. Two other interviews were selected from the private channel Antena 3. The two interviews were conducted by the News Programs Director, one with the then Prime Minister, José Luis Rodríguez Zapatero, and the other with the leader of the opposition Mariano Rajoy. The time range extends from 2009 to 2012. 
Following the theoretical model we have adopted, the working methodology consisted of identifying the argumentative strategies employed to express confrontation and assessing which are polite or impolite. Since this article aims to establish that the presence of impolite strategies is a constitutive feature of these new formats in Spanish television, our study is mainly qualitative. With this aim, and in order to avoid any kind of ethnocentrism, we identified and described in detail all the factors which influence each of these television formats: the features characteristic of the Spanish sociocultural community, the defining characteristics of the commmunicative genre and the communicative situation, the participants, their relationship to each other and the topic discussed.

Apart from contextual factors and knowledge shared with the community, an interpretation of impoliteness is derived from the reactions of the audience and of the participants themselves. For instance, example 1 shows the female IR's anger at accusations of partiality made by her female guest concerning her news program (political interview), whereas example 2 highlights the complaints expressed by the female IE in relation to the treatment received at the hands of the IR (gossip press interview):

(1) $\left[\mathrm{IE}^{5}:(\ldots / /)\right.$ ser de una objetividad meridiana y de una imparcialidad meridiana/ y/ mire usted/ aunque a algunas personas les moleste/ sobre todo a los dirigentes de Televisión Española [yo le tengo que decir=]

IR: [y a los trabajadores/se lo aseguro]

IE: =bueno/ a algunos les molestará/ a otros estoy segura que no/ se lo tengo que [decir=]

IR: $[n o]$

IE: $=$ a otros estoy segura que no]

[IE: (...//) be guided by crystal-clear objectivity and crystal-clear impartiality/ and/ look/ even though it may annoy some people/ above all the top management of Television Española [I must tell you=]

IR: [and the employees/I can assure you]

IE: =well/ some will be annoyed/ others will not, I'm sure/ I must [tell you=]

IR: [no]

IE: = others will not, I'm sure] (“Los desayunos de TVE,” April 26, 2011)

(2) IR: [Sonia, qué cutre eres] de verdad

IE: a mí no me insultes tú, no me insultes tú [es que no, es que es una cuestión, es que si a mí no, es que a mí no me llames tú cutre porque, porque la persona $<<\ldots>>$ ]

IR: [sabes que no, es que es una cuestión ya, es que eres muy cutre, sí, sí, te lo digo a la cara, cutre, cutre]]

[IR: [Sonia, you are so tacky] really

IE: you don't insult me, don't insult me [it is not, I mean it is a question, it is not about if you don't call me, you don't call me tacky, because the person $<<\ldots>>$ ]

IR: [you know it is not, it is already a question, I mean you are so tacky, yes, yes, I can tell you to your face, tacky, tacky]] ("La Noria," May 30, 2009)

Other factors which attest to this evaluation are the reactions of the viewers, who may send text-messages, which then appear on screen or write comments which are posted on various internet forums and social media.

\section{Verbal (Im) Politeness on Television}

\subsection{Previous Studies}

Traditionally, the study of verbal (im) politeness has been carried out on face-to-face interactions. Since the mid 1990s research on impoliteness has mostly focused on institutional communication (Lakoff, 1989; Penman, 1990). Nevertheless, given the dependence of this phenomenon on enunciative parameters, a comprehensive characterization of verbal (im) politeness requires complementing the analysis of its formalization in conversation with the study of other types of communicative interactions. Modifying the communicative situation can even result in the alteration of the features or the function of this phenomenon (Spencer-Oatey, 2007).

In this respect, im(polite) verbal expressions in television discourse were first analyzed in 2003 by Culpeper et al. Since then, a number of studies have focused on television quiz shows (Culpeper, 2005), British or American talk shows (Lorenzo Dus, 2009), television debates (Blum-Kulka, Blodheim, Hacohen, 2002; Lunginbühl, 2007), television interviews in English (Greatbatch, 1992; Emmertsen 2007), and also on English television discourse as a whole (Lorenzo Dus 2009). In the specific case of Spanish, some of the most important studies are analyses of blatant impoliteness in chat shows (Brenes Peña 2011, Brenes-González 2013, Placencia-Fuentes 2013), talk shows (García 
Gómez, 2000), reality shows (Garcés et al. 2013; Blas Arroyo, 2014) and quiz competitions (Brenes Peña 2009, 2013). We were unable to find any detailed study on this type of discourse which included the divergences caused by the type of program or the style adopted. This paper therefore seeks to bridge this gap.

\subsection{Impoliteness as a Feature of Genre (or Exploitative Variant)}

The studies cited above point to a phenomenon already described by Culpeper (2005) in his pioneering study: verbal impoliteness has generated a new television format. Culpeper $(2005,46-47)$ adopts the expression 'exploitative variants' to describe it: "What truly separates the exploitative chat shows from the standard shows is that they are all characterized by impoliteness. (...). Exploitative shows have evolved through the subversion of the politeness norms of the standard shows." Verbal impoliteness in Spain has also impinged on the superstructure (Van Dijk 2002) of certain programs. This substantially alters the communicative purpose, the obligations associated with the different roles, and the topics dealt with:

Everything that used to be forbidden is allowed in these new television genres in a process of approximation to the general population, who thus see television not as a 'fiction' but as another part of their lives. The aim is to identify with viewers, with their emotions, their conflicts and even their boring routines. The strategy of scandalizing and breaking rules has the sole aim of providing an innovative feature to capture the spectators' attention. A new format is thus generated, and doubts arise in relation to the purpose of a conversation: it is no longer meant to seek agreement but rather to spring surprises (Fuentes Rodríguez and Brenes Peña 2011, 66, our translation).

This tendency first emerged in talk shows which sought to win the acceptance of a more diversified audience, no longer confined to the average housewife (Brenes Peña 2011). The success achieved led to the extension of impoliteness to other discursive types where it plays different roles ${ }^{6}$.

This type of interview represents another step in the shift described by Clayman and Heritage (2002), where the IR still strives to appear neutral. The goal of this new television interview is to reaffirm the TV channel's, or program producer's opinion concerning a given IE. For this reason the strategies based on impoliteness and the criticism of the IE's face are preferably directed at those who variously deviate from the program's ideology, which tends to coincide with the values of the viewers who regularly follow such interactions ${ }^{7}$. The IR openly disagrees with answers contradicting the positions defended by the news program and uses a range of tactics to coerce the IE into providing the answers the IR and the viewers want to hear. In fact, the time taken up by the IR in his/her speaking turns is longer than that used by the IE, which runs counter to what is customary in the traditional interview genre, where the prominent role is always accorded to the $\mathrm{IE}^{8}$.

It is our aim in this paper to examine the extent to which the television interview genre has been affected by the aforementioned shift in the IRs and in this context to explore the role of the thematic variation, a feature which has not previously received attention.

\section{Television Interview in Spain: Impoliteness and Thematic Variation}

\subsection{The Televised Interview in Spain. Characteristics}

According to Cortés Rodríguez \& Bañón Hernández (1997) and Haverkate (1998), the interview has been defined as a discursive genre based on the adjacent question-answer pair, which essentially has an informative purpose: to obtain as much information or opinion as possible from an IE concerning a given topic. However, our analysis has shown that this goal may be modified according to the topic addressed in the interview. Interviews with celebrities basically seek to entertain viewers, as the topics under discussion are largely of secondary importance.

In our corpus, there are also differences regarding the people involved in the interaction. The IE generally tends to be someone who is in the spotlight for whatever reason. In this respect, the divergences between political interviews and those involving celebrities lie in the status of the person who conducts the interview. In the political context, the role of the IR is usually performed by well-known and respected journalists. The IRs who conduct tabloid television interviews are known for their skills in confrontation with guests rather than for their professional training.

Finally, our analysis has shown that the two subtypes of interviews analyzed differ in register. The register in political interviews is more formal, whereas interviews with celebrities are marked by their colloquial tone. The divergence between both subtypes is so pronounced that it would be unthinkable to exchange the linguistic modality adopted in the two categories. The relative triviality of the issues addressed in tabloid television interviews is matched by the often undesirable status of the IE. This leads to the use of a certain register and communicative behavior that would be absolutely out of place in interviews with people from the political sphere.

\subsection{Impolite Strategies}

Taking into account the features mentioned above, our main concern is to determine the communicative behavior 
regarded as polite in television interviews. Thus, attention must be paid to the relationship of functional asymmetry existing between the roles of IR and IE. In functional terms, the IR will always enjoy a higher position in the enunciative hierarchy of this format, since it is he or she who has control over the planning of questions and, to some extent, over the adequacy of the answers offered; IRs may simply and pointedly repeat a question if they consider it to have been poorly answered.

As Cortés and Bañón $(1997,48)$ suggest, "the IR must not be too explicit about his/her dominant role, as this would negatively affect the IE's behavior" (our translation). In other words, as Fuentes Rodríguez (2006, 75) explains, politeness in the television interview would consist in "achieving as much benefit as possible in obtaining all the necessary information, while praising the other's face. It follows then an agreeable atmosphere should be created for the IE, so that he or she can feel comfortable and, consequently, talk" (our translation). The adjacent question-answer pair on which this genre is based implies a certain degree of restriction on the IE's freedom of expression. Hence, the IR should not attack the IE's face, and refrain from coercing or insulting; otherwise, the IE will not provide the IR with the information he or she is seeking.

The analysis of the twenty interviews, according to the methodology set out in section 2, showed that the role of the IR made use of the following impolite verbal strategies, which will be analyzed in detail in the next section:

o Criticizing the IE's evasiveness. Disagreeing with the IE about what has been said.

o Using inferences strategically.

o Accusing the IE of breaking the maxim of quality.

o Using ad hominem argument. Attacking the personal features of the IE

o Undervaluing the IE's discourse.

o Interrupting the communicative exchange

In order to arrive at a polite or impolite assessment, an emic rather than ethic perspective must be adopted. Taking the discourse into account from a relational work point of view, the assessment is made on the basis of perceived appropriateness of behavior. Formally, this behavior is impolite, but the effect is attenuated by the genre, or is accepted. Therefore we must not equate what is not accepted with impoliteness. The norm differs from the standard in this genre as does public acceptance. The behavior (and means employed) is impolite, but predictable, since they constitute the rules of the game. We propose to call it "formal impoliteness".

\section{Analysis of Impolite Strategies Results}

\subsection{Sanctioning the IE's Evasiveness}

One of the IR's functions is to ask IEs the sorts of inconvenient or awkward questions that might be of interest to viewers. Interestingly, IEs can react to such questions avoidance of a direct answer, employing circumlocution or any other rhetorical strategies available to them. Should this occur, the IR may repeat the question, perhaps rephrasing it, but always addressing the same issue. An impolite social effect occurs when IRs openly sanction the IE's attitude, since they thus present the IE as someone who does not abide by the conversational contract intrinsic to the genre 9

Political interviews and those that involve celebrities differ in this respect only in terms of register. In the political interview, IRs in both subtypes openly reprimand their guests for evasiveness (3), and may even claim their enunciative superiority (4). Nevertheless, the more informal register in chat shows with celebrities makes possible the use of expressions such as those in (5):

(3) [IR: Presidente/ el año ha empezado con una empinada cuesta de enero con subidas en la luz/ el gas/ el butano/ la electricidad/ y esto cuando se acaba el cheque-bebé/ los $426 €$ para los desempleados de larga duración y la desgravación por vivienda. ¿De verdad sigue pensando que la salida a la crisis será social?

IE: (...) pero para que tengamos a más jóvenes/ sobre todo a los que han perdido el empleo/ con más oportunidades/ tenemos que hacer más hincapié en las políticas ACTIVAS y de formación que en las políticas pasivas

IR: todavía no me ha contestado si sigue pensando que la crisis sería social/ la salida]

[IR: Mr. President/ the year has started with a steep 'January hill' with price increases in (natural) gas/ butane/ electricity/ and this when the 'baby-check'/ the $426 €$ for the long-term unemployed and the tax deduction for the acquisition of a primary residence all come to an end. Do you still really think that the way out of the crisis will be a social one?

IE: (...) but, in order to have more young people/ especially those who have lost their jobs/ with more opportunities/ we must place more emphasis on ACTIVE and training policies better than in passive policies 
IR: you still have not answered me about whether you still think the crisis/ the solution would be social] ("Informativos de Antena 3," January 10, 2011)

(4) [IE: que no voy a comentar eso, de las maneras// hay temas muy importantes en España y en el mundo para que vayamos a hablar de este tema

IR: bueno/ ya sabe que aquí los asuntos no sólo los decide usted/los decidimos también aquí en esta mesa]

[I: I mean, I am not going to comment on that, on manners// there are very important issues in Spain and in the world for us to start talking about this topic

IR: well you already know that it is not up to you to decide the issues (treated) here/ that is also decided here on this table] ("Los desayunos de TVE," October 14, 2010)

(5) [IE: Jose Antonio/ has conta(d)o lo que te ha da(d)o la gana

IR: no/ he contao/ he contao lo que tenía que contar]

[I: Jose Antonio/ you've told us just whatever you liked

IR: no/ I told/ I told what I had to tell] ("La Noria," January 15, 2011)

The use of this impolite strategy in both interview subtypes with the same level of intensification is due to the positive social effect accruing to the IR's face. Explicitly denouncing the IE's evasive attitude is a strategy that produces an impolite face-threatening effect but at the same time it serves to enhance the image of the journalist as someone who will not allow himself to be pushed around or deceived by the politician. In short, what the IR achieves in this way is to demonstrate his/her freedom with regard to the IE's utterances, and underscore a quality that is especially appreciated in this context, a determination to provide viewers with the information they are entitled to expect.

\subsection{Disagreeing with the IE about What Has Been Said}

The IRs in these TV programs are not neutral, as Heritage $(1985: 99)$ claims ${ }^{10}$; they make no attempt to conceal their skepticism, disagreement or disbelief with regard to what has been said. How to verbalize this impolite strategy varies according to the type of interview.

Our analysis shows that, in interviews with politicians, the IR may disagree with the opinions expressed, but always indirectly and without ridiculing the IE. On the other hand, interviews with celebrities represent a further stage within the spiral of verbal impoliteness. This is illustrated in the following two extracts:

(6) [IE: DISCREPO absolutamente de la dirección política de Televisión Española

IR: Bueno/ yo le digo que no hay una dirección política [hay una dirección profesional=]

IE: [se lo vuelvo a decir]

IR: = por cierto/ elegida también por la dirección del PP

IE: Bueno/ perfecto/ usted tiene su opinión/ pero yo le hablo en nombre del Partido Popular]

[I: I totally DISAGREE with the political management of Televisión Española

IR: Well/ I can tell you that there is no political management [there is a professional management=]

I: [I tell you once again]

IR: = by the way/(she was) also chosen by the PP management

I: Well/ perfect/ you have your opinion/ but I am speaking to you on behalf of the Popular Party]

(“Los desayunos de TVE,” April 26, 2011)

(7) [IR: mira/ eres tan poco interesante que no me das ni asco/Sonia]

[IR: look/ you're so uninteresting that you don't even disgust me/ Sonia] (“La Noria," May 30, 2009)

As it can be seen in these examples, the IR makes no pretence of neutrality with respect to the opinions expressed by the IE. In (6), the journalist rebuts the female IE's assertion concerning the lack of impartiality in TVE's news services. However, based on the addressee's reaction, we can say that the damage to the IE's face is much more serious in (7), where the IR openly abuses the IE using highly offensive language. Therefore, in the (im)politeness continuum, (7) is closer to the impolite zone.

\subsection{Using Inferences Strategically}

In the two kinds of interviews, discourse progression sometimes forces IRs to refer to what the IE has said by summarizing or interpreting their words. Confrontation with the IE arises when such rephrasings or summaries are 
made with a mischievous intention. That is to say, IRs reinterpret what has been said by the IE in order to arrive at conclusions that suit their own interests. They also control the interview, channelling it in a chosen direction .In the extract below a female IR tries to force her female IE to admit her opposition to a measure that had just been adopted by the Council of Ministers concerning the speed limit permitted in Spanish motorways and highways. With this aim, the IR starts by presenting an objective fact (discussion of the issue in the Council of Ministers) and then uses it to pose her question. Since the discussion of the issue is common knowledge, the IE has no choice but to answer the question, which in other circumstances she might choose to avoid. Only when the IR realizes she cannot obtain the desired outcome does she choose to infer information, create an implicature from the IE's utterances, and oblige her to respond, even though -as can be observed- the IE flatly refuses to:

(8) [IR: el pasado viernes se habló en el Consejo de Ministros - se decidió de nuevo aumentar el límite de velocidad a los 120/ ¿Ha perdido la batalla la Vicepresidenta Salgado?

IE: no/ bueno/ en primer lugar/ a mí me sorprende que se hable de los debates en el seno del Consejo de Ministros§

IR: § pues solo puede salir de un sitio Vicepresidenta/ y es de los que estáis/ de los que están ahí sentados/ ¿no?/ digo yo/ vamos

IE: bueno/ las decisiones/ como se sabe/ son decisiones de todos/ no son decisiones de uno o de otro/ la decisión es una decisión de todos/ también es verdad que si todos los Ministros pensáramos igual de todas las cosas/ sería $\rightarrow$

\section{IR: así que no pensaba usted que hubiera que cambiar el límite]}

[IR: last Friday the Council of Ministers discussed - decided to raise the speed limit back to 120 / has Vice President Salgado lost her battle?

IE: no/ well/ in the first place/ it surprises me how people can speak about the debates within the Council of Ministers§

IR: $\S$ well, it can only come from one place, Vice President/ and it is from you who are there/ you all, who are sitting there/ can't it?/ (that's what) I would say/ at least

IE: well/ the decisions/ as everyone knows/are the decisions of all of us/ they are not decisions adopted by one (minister) or another/ the decision is a decision made by all of us/ it is also true that if we all as Ministers had the same opinion about every issue/ that would be $\rightarrow$

IR: so you didn't think the limit had to be changed] ("Los desayunos de TVE," June 27, 2011)

Occasionally, journalists in celebrity interviews also strategically exploit inferences in order to reorient what the IE has said or to present information or opinions that the IE has not expressed as if they had actually done so. An example of this can be found in the following extract, in which an IE disagrees with how the IR summarizes the problems he has had to overcome in the bullfighting world, because of the undesirable inferences involved.

(9) [IR: [pero Paloma/ a mí me ha parecido entender] perdona/ a mí me ha parecido entender que Canales Rivera está diciendo que no ha toreado porque sus primos lo han vetao/ ¿es así o no?

IE: a mi la palabra "veto"/ la palabra "veto" la verdad es que no me gusta en absoluto]

IR: [but Paloma/ as I understood it] excuse me/ as I understood it, Canales Rivera is saying that he has had no bullfights because his cousins have vetoed him/ is that true or not?

IE: for me, the word 'veto'/ the truth is I don't like the word 'veto' one bit] (“La Noria," January 15, 2011)

\subsection{Accusing the IE of Breaking the Maxim of Quality}

The IRs who takes part in the two types of interview analyzed frequently manifest their incredulity at the IEs' opinions. Bearing in mind that it is their professional duty to obtain reliable information, it is logical that the IR should ensure that questions are properly answered and that IEs observe the maxim of quality. In interviews with people from the world of politics, the IR usually verbalizes this impoliteness strategy in a rather attenuated way (10). In celebrity interviews the IR is more overtly impolite (11).

(10) [IR:(...)¿por qué es diferente el caso de Ternera del de Troitiño?

IE: $(\ldots)$

IR: Realmente/ cuesta ver la diferencia/ se lo digo porque es verdad que él era diputado/ lo cual no le exime de cometer un delito/ lo único que le va a juzgar el Supremo y no [cualquier tribunal/ pero él fue llamado para una causa]

(...)

IE: Claro/ a usted le costará ver la diferencia/ como me dice usted que [le cuesta ver la diferencia=]

IR: [me cuesta/ sí] 
[IR:(...)why is Ternera's case different from that of Troitiño?

IE: $(\ldots)$

IR: Really/ it is hard to see the difference/ I'm telling you because it is true that he was a Member of Parliament/ which does not exempt him from committing a crime/ the only thing is (that) he will be judged by the Supreme (Court) and not by [any court/ but he was summoned for a lawsuit]

(...)

IE: Of course/ you must find it hard to see the differencel as you tell me that [it is hard for you to see the difference=]

IR: [I do find it hard, yes] ("Los desayunos de TVE," April 26, 2011)

It is also worth highlighting here that the IR initially presents her criticism impersonally: cuesta ver la diferencia [it is hard to see the difference], thus mitigating any imputation of impoliteness. Only after the beleaguered IE repeats the expression does the interviewer lay personal claim to the opinion. As regards the other interview subtype, these same accusations present a higher degree of direction and intensification. An illustration can be found in the following excerpt, where the IR repeatedly and openly casts doubt on the IE's truthfulness and does not hesitate to interrupt him:

(11) [IR: (...) insisto/ que me parece muy bien/ ¿qué/ pasa/ contigo y con tus primos? ¿qué mal rollo hay?

(...)

IR: [que no hablemos de/ que no tiene nada que ver con] que no me creo que sea NADA de temas de empresarios/ que no me lo creo/vamos a ver [que entiendo/ que el mundo del toro lo entiendo]

IE: [¿no? bueno/ de empresarios/ no/ es profesional] es un tema profesional

IR: que no/ que no/ que no me lo creo/ que no me lo creo]

[IR: (...) I insist/ I'm perfectly happy/ what's/ the matter/ with you and your cousins? what's wrong?

(...)

IR: [I mean, let's not talk about/ you see, it has nothing to do with] I mean, I don't see it's a question of about promoters AT ALL/I mean, I don't believe it/ let's see [you see, I understand/I understand the bullfighting world]

IE: [you don't? well/ about promoters/ no/ it's professional] it's a professional issue

IR: you see, I don't/ you see, I don't/ I mean, I don't believe it/ I don't believe it, you know] ("La Noria", January 15, 2011)

5.5 Using Ad Hominem Argument Attacking the Personal Features of the IE

An easy way to undermine the message is to belittle the speaker. Thus, the IE is presented in a sufficiently negative light for their position to be rejected by association. Such ad hominem tactics rely on "providing arguments which do not refer to the content of the actual reasoning and its validity, but serve to achieve victory by exerting pressure upon the person and questioning his or her credibility" (Lo Cascio, 1998, 292, our translation).

Nevertheless, the higher degree of impoliteness implied in this mechanism accounts for its absence in the political interviews analyzed. In spite of it being very common in political discourse (Ilie 2004, Bolívar 2008), IRs at most employ questions that implicitly convey some criticism of the IE. Thus, the journalist questions the trust inspired by the then leader of the opposition, Mariano Rajoy, by citing a survey carried out by the CIS [Centre for Sociological Research]. However, the journalist does not necessarily subscribe to this opinion herself. She merely presents data, which damage the politician's face:

(12) [IR: Señor Rajoy/ usted ha dicho que los mercados aprietan por la falta de credibilidad política del presidente Zapatero// ¿tienen motivos los mercados para fiarse de usted? Porque el CIS/ la confianza en el CIS/ ahí tampoco sale usted muy bien parado]

[IR: Mr. Rajoy/ you said that the markets are applying pressure due to President Zapatero's lack of political credibility// do the markets have reasons to trust you? Because the CIS/ trust in the CIS/ you don't come too well there either] ("Informativos de Antena3," January 24, 2011)

However, in interviews involving celebrities, criticisms, accusations and defamatory remarks can be stinging and highly personal. Rude language causes considerable impact and captures the addressee's full attention, thus highlighting what has just been said:

(13) [IR: esta tía es imbécil/ Jordi/ esta tía es imbécil]

[IR: this woman is stupid/ Jordi/ this woman is stupid] ("La Noria," November 13, 2010) 


\subsection{Undervaluing the IE's Discourse}

Another impolite strategy which is confined to tabloid television is to discredit the IE's discourse. IRs conducting political interviews at most draw attention to the inconsistencies or contradictions found in the IE's line of argument. In interviews with celebrities, well-reasoned counter-argumentation may degenerate into an exchange of insults. The IE's discourse may be characterized initially as false and contradictory, but then also as absurd, immoral and even surreal, all of which deprives the argumentation presented of any dialectic value.

(14) [IR: Te dolería más por él $\rightarrow$

IE: es diferente el malestar// él es el culpable de haber roto el matrimonio/ pero ella se tenía que haber quedado en su sitio/ el que le correspondía/ el de amante

IR: me parece inmoral que digas una cosa así de una mujer]

[IR: You'd be hurt more for him $\rightarrow$

IE: the upset's different// he's the one to blame for the marriage breaking down/ but she should have stayed in her place/ the one that was hers/ to be the lover

IR: it seems immoral to me that you should say something like that about a woman] (“La Noria," November 11, 2009)

\subsection{Interrupting Communicative Exchange}

The impoliteness encountered in celebrity interviews can lead to acrimonious confrontation, so much so that the IR, taking umbrage at the IE's words, may decide to leave the studio or stage and put an end to the interview. This radical infringement of the cooperative principle occurs twice in the interviews analyzed. The following is one of these two cases:

(15) [IE: usted ha dicho que yo me he aprovechado/ que USTED ha dicho que yo me ha aprovechado de no sé qué cosas QUE ME EXPLIQUE USTED de qué me he aprovechado yo y quién me ha beneficiado a mí/ ex -plí-que-me-ló

IR: le dije hace un rato que usted ha ido de víctima desde hace mucho tiempo [sin que nadie lo persiguiera]

IE: [pero diga un nombre] conteste sí o no/ ¿es usted puta o no es puta? (APLAUSOS)

IR: yo no

IE: dígame/ dígame quién me ha beneficiado a mí/ o sea/ quién me ha apoyado a mí/ qué partido político

IR: yo no tengo por qué aguantar este insulto/ ni estoy cinco minutos más sentada aquí al lado de una persona que tiene la poca vergüenza de insultar a una mujer. (SE MARCHA DEL PLATÓ. APLAUSOS, GRITOS)]

[IE: [you said I have taken advantage/ I mean, YOU said I have taken advantage of I don't know what] I AM TELLING YOU TO EXPLAIN what I have taken advantage of and who I've benefited from/ ex -plain-it-to-me

IR: I told you a while ago that you have played the role of a victim for a long time [even though nobody chased you]

IE: [but mention a name] answer yes or no/ are you a whore or not? (APPLAUSE)

IR: I'm not

IE: tell me/ tell me who's benefitted me/ that is to say/ who's supported me/ which political party

IR:I don't have to put up with this insult/ and I am not going to sit here even for five minutes more sat here beside a person who is shameless enough to insult a woman. (SHE LEAVES THE STUDIO. APPLAUSE, SHOUTS)] ("La Noria", April 16, 2010)

This breakdown of communication due to confrontation and verbal impoliteness would be unthinkable in the traditional configuration of this genre. Such an eventuality was not envisaged in the television interview based on the adjacent question-answer pair. The genre has undergone a transformation marked by verbal impoliteness, which has substantially altered its features. However, as has been observed in our examples, this transformation has not affected all types of interview to the same extent.

Establishing a continuum, interviews on political issues may be said to remain closer to the prototype, whereas celebrity interviews are characterized by confrontation and a marked colloquial style that takes them closer to exclusive impoliteness (Brenes Peña 2011; Briz 2013).

\section{Discussion: Functions of Verbal Impoliteness in Interviews}

The analysis of our corpus has shown that verbal impoliteness is used for different purposes in the two subtypes of interview studied. The reason lies in audience expectations, which not only determines the topics, the participants and the configuration of the television format but also decisively influences the selection of the social effect caused. 
In political interviews, the use of verbal impoliteness is closely associated with the construction of one's face. The IR seeks to present him -or herself- as an impartial professional who does not take sides or follow the dictates of any political party. Consequently, (s) he does not hesitate to threaten the face of the socially more powerful IE, in order to obtain the information the viewers' demand. Furthermore, this implacable attitude to the IE allows the IR to win over viewers, who feel that the IR is confronting the IE in search of the truth. The ultimate goal of this impoliteness is, therefore, to achieve alignment with viewers and create an identity. The IR damages the IE's social image with the aim of establishing a coalition with the public.

As for interviews involving celebrities, the use of verbal impoliteness has another essential goal: not so much to create an ideological alliance with the public as simply to excite their interest, to capture viewers' attention, to amuse and entertain them by transgressing what is regarded as socially acceptable. The subversion of normal expectations generated by defamatory remarks in the interviews analyzed captures the viewer's full attention. The celebrity interviews analyzed here, in which the interlocutors adopt the 'anything goes' approach so as to attract the highest number of viewers, manifest the entertainment value of the verbal dimension of violence. This is always present, for instance, in quiz shows (Culpeper et al. 2003, Brenes Peña 2009) and television documentaries (Culpeper et al. 2003; Bousfield 2008), where the selection of broadcast images is based on the level of verbal impoliteness they exhibit. This is therefore another example of the media-ludic impoliteness described in Brenes Peña (2011) with regard to chat shows with celebrities, in which impoliteness is a device employed to shock and amuse the viewer.

Since the impoliteness is already a feature of this genre, IE and IR do not perceive that his face has been discredited. But the viewers evaluate these strategies as impolite. A proof of this is their comments in chats. Impoliteness is a means to capture the viewers' attention. This is a formal impoliteness used as a strategy.

\section{Conclusions}

The analysis of our corpus has shown that the current television interview differs from the traditional format of this genre in a number of respects. Impoliteness is used in Spanish interviews as a component that alters their format and produce "hibridity", (Ekstrom 2011) between interview and talk-show. Its fundamental goal is to attract the audience and to build the journalist's face in political interviews as participants in ideological confrontation. Nevertheless, the detailed study of the impoliteness strategies employed by the interviewer has shown that the modification of features largely depends on the subtype examined, which is why no generalizations can be made in this respect. This moreover explains why a variationist perspective has been adopted in the analysis of verbal impoliteness (Barron-Schneider 2008).

The element which is common to all the interviews analyzed and which, from our viewpoint, has given rise to the current television interview format, is the figure of an incisive IR who does not allow the IE to manipulate him or her and conduct a non-accommodating type of interview (Haverkate, 1998). In the programs analyzed, the IR never chooses to empathize with the IE. On the contrary, the IR queries the answers provided and tries to ensure that the IE is not evasive. He or she also highlights the inconsistencies in the IE's argument and indicates disagreement when the IE is suspected of insincerity or subterfuge. This shift coincides with what has been observed in other countries and other television interview programs (Greatbacht, 1992; Clayman y Heritage, 2002).

In political interviews, the new role of the IR emerges because he/she has become the viewers' champion at a time when viewers are increasingly disillusioned with politicians. The politician comes to the interaction with the clear goal of winning the favor of the electorate. For their part, the IR's main objective is to ensure that IEs are aware of the viewers' perception of reality. Faced with the evasion tactics of the politicians (Rasiah 2010), IRs seek to uncover the truth and satisfy the viewers' expectations.

The IR's role in interviews involving celebrities also conforms to the detective or forensic role described by Arfuch (1995), but as the issues discussed in these sorts of programs tend to be neither important or novel, the informational interest is insignificant. The viewer's attention, thus, is captured by means of strategies that do not involve disclosing new information. The best way to achieve this, of course, is by means of something not socially expected or sanctioned: verbal impoliteness. In other words, its capacity to provoke together in the context of the lower degree of formality in this genre make verbal impoliteness a preferred resource.

As a result, the interview can end up drifting towards another genre in the most extreme situations. What was initially a genre based on the adjacent question-answer pair becomes an acrimonious confrontation based on the adjacent assertion-rejection pair, where good manners are largely ignored. The interactive purpose of these interviews is consequently not to induce the IE to provide relevant information on a current issue but to degrade the IE's face.

Moreover, in television celebrity interviews we observed a wider range of strategies of verbal impoliteness, which are absent from political interviews. Thus the strategies labelled 'underevaluing the IE's discourse' or 'interrupting the 
communicative exchange' are exclusively a feature of interviews with media celebrities. As for common strategies, the dissimilarities refer to the linguistic material by means of which they are formalized. Thus, depersonalization of criticism, doxastic mitigation and preference for indirection are strategies typical of interviews related to politics.

In conclusion, in the programs analyzed verbal impoliteness can be said to have become a characteristic of the interview genre albeit to varying degrees and with different functions depending on the subtype. Establishing a continuum, interviews on political issues remain closer to the prototype, whereas celebrity interviews are characterized by confrontation and a markedly colloquial register that brings them closer to exclusive impoliteness. The issue discussed in this genre, political or social, is a highly relevant factor in this regard, which reaffirms the need to adopt a variationist approach.

\section{Acknowledgements}

This study forms part of a broader project on (im)politeness in media discourse, funded by the Spanish Ministry for Science and Innovation (FFI 2009-10515) and the European Development Fund, and the project P-10 HUM 5872 funded by the Junta de Andalucía, Consejería de Economía, Innovación y Ciencia.

\section{References}

Arfuch, L. (1995). La entrevista, una invención dialógica. Barcelona: Paidós.

Arundale, R. B. (2010). Constituting face in conversation: Face, facework, an interactional achievement. Journal of Pragmatics, 42, 2078-2105. https://doi.org/10.1016/j.pragma.2009.12.021

Blas Arroyo. J. L. (2014). Factores condicionantes en la producción y recepción de la descortesía en un reality show. Una aproximación variacionista. Revista de Filología de la Universidad de La Laguna, 32, 17-43.

Blum-Kulka, S. (1983). The Dynamics of Political Interviews. Text, 32, 131-155. https://doi.org/10.1515/text.1.1983.3.2.131

Blum-Kulka, S., Blodheim, M., \& Hacohen, G. (2002). Traditions of dispute: from negotiations of talmudic texts to the arena of political discourse in the media. Journal of Pragmatics, 34(10-11), 1569-1594. https://doi.org/10.1016/S0378-2166(02)00076-0

Bolívar, A. (2008). 'Cachorro del imperio' vs. 'cachorro de Fidel': los insultos en la política latinoamericana. Discurso y Sociedad, 2(1), 1-38.

Bousfield, D. (2008). Impoliteness in Interaction. Amsterdam/Philadelphia: John Benjamins Publishing Company. https://doi.org/10.1075/pbns.167

Bravo, D. (2004). Tensión entre universalidad y relatividad en las teorías de la cortesía. In D. Bravo \& A. Briz (Eds.), Pragmática sociocultural: estudios sobre el discurso de cortesía en español (pp. 15-37). Barcelona: Ariel.

Brenes Peña E. (2013a). Interviews as confrontation, el nuevo entrevistador televisivo. In C. Fuentes Rodríguez (Ed.) Imagen social y medios de comunicación (pp.25-52). Madrid: Arco Libros.

Brenes Peña, E. (2009). Grados de descortesía en la expresión de juicios y valoraciones negativas. Un caso concreto: Risto. Interlingüística, 18, 178-189.

Brenes Peña, E. (2011). Tertulia televisiva y descortesía verbal. Análisis pragmalingüístico. Bern: Peter Lang. https://doi.org/10.3726/978-3-0351-0159-1

Brenes Peña, E. (2013b). La descortesía mediático-lúdica en los programas de entretenimiento. El rol del jurado agresivo. In C. Fuentes Rodríguez (Ed.) Imagen social y medios de comunicación (pp.145-156). Madrid: Arco Libros.

Brenes Peña, E., \& González Sanz M. (2013). El tertuliano agresivo. In C. Fuentes Rodríguez (Ed.) Imagen social y medios de comunicación (pp.121-144). Madrid: Arco Libros.

Briz Gómez. A. (2013). Variación pragmática y coloquialización estratégica. El caso de algunos géneros televisivos españoles (La tertulia). In C. Fuentes Rodríguez (Ed.), (Des)cortesía para el espectáculo: estudios de pragmática variacionista (pp. 89-125). Madrid: Arco Libros.

Brown, P., \& Levinson, S. (1987). Politeness. Some Universals in Language Use. Cambridge: CUP.

Bucholtz, M., \& Hall, K. (2005). Identity and interaction: a socio-cultural- linguistic approach. Discourse Studies, 7, 4-5, 585-614. https://doi.org/10.1177/1461445605054407

Clayman, S., \& Heritage, J. (2002). The News Interview: Journalists and Public Figures on the Air. Cambridge: Cambridge University Press. https://doi.org/10.1017/CBO9780511613623

Cortés Rodríguez, L., \& Bañón Hernández, A. (1997). Comentario lingüístico de textos orales II. El debate y la entrevista. Madrid: Arco Libros. 
Culpeper, J. (2005). Impoliteness and entertainment in the televisión quiz show: The Weakest Link. Journal of Politeness Research, 1(1), 35-72. https://doi.org/10.1515/jplr.2005.1.1.35

Culpeper, J., Bousfield, D., \& Wichmann, A. (2003). Impoliteness revisited: with special reference to dynamic and prosodic aspects. Journal of Pragmatics, 35(10-11), 1545-1579. https://doi.org/10.1016/S0378-2166(02)00118-2

Ekström, M., \& Patrona, M. (2011). Talking politics in broadcast media: cross-cultural perspectives on political interviewing, Journalism and accountability, Amsterdam: John Benjamins. https://doi.org/10.1075/dapsac.42

Emmertsen, S. (2007). Interviewers' challenging questions in British debate interviews. Journal of Pragmatics, 39(3), 570-591. https://doi.org/10.1016/j.pragma.2006.07.011

Fuentes Rodríguez, C. \& Brenes Peña E. (2011). Descortesía verbal y televisión: hacia una nueva superestructura. In S. Alcoba \& D. Poch (Eds.), Cortesía y publicidad (pp. 61-76). Barcelona: Ariel Letras.

Fuentes Rodríguez, C. (2000). Lingüística pragmática y Análisis del Discurso. Madrid: Arco Libros, 3 ed. 2017.

Fuentes Rodríguez, C. (2006). Cortesía o descortesía? La imagen del entrevistado vs. La imagen del entrevistador. Cultura, lenguaje y representación. Revista de estudios culturales de la Universitat Jaume I, III, 73-88.

Fuentes Rodríguez, C. (2010a). La gramática de la cortesía en español/LE. Madrid: Arco Libros.

Fuentes Rodríguez, C. (2010b). Ideología e imagen: la ocultación en la prensa de la violencia social o lo políticamente correcto. Discurso y Sociedad, 4(4), 853-892.

Fuentes Rodríguez, C. (2011). (Des)cortesía y violencia verbal: implicaciones lingüísticas y sociales. In C. Fuentes Rodríguez, E. Alcaide Lara \& E. Brenes Peña (Eds.), Aproximaciones a la (des)cortesía verbal en español (pp. 27-75). Berna: Peter Lang.

Fuentes Rodríguez, C. (2013). Identidad e imagen social. In C. Fuentes Rodríguez (Ed.) Imagen social y medios de comunicación (pp. 13-21). Madrid: Arco Libros.

Fuentes Rodríguez, C.. (2016). (Des)cortesía, imagen social e identidad como categorías sociopragmáticas en el discurso público. In D. Dumitrescu \& D. Bravo (Eds.) Roles situacionales, interculturalidad y multiculturalidad en encuentros en español (pp. 165-192). Buenos Aires: Dunken.

Garcés-Conejos, B. P., Lorenzo-Dus, N., \& Bou-Franch, P. (2013). Identity and impoliteness: The expert in the talent show Idol. Journal of Politeness Research, 9(1), 97-121. https://doi.org/10.1515/pr-2013-0005

García, A. (2000). Discourse, politeness and gender roles: an exploratory investigation into British and Spanish talkshow verbal conflicts. Estudios Ingleses de la Universidad Complutense, 8, 97-125.

González Sanz, M., \& Brenes Peña E. (2013): El nuevo moderador (contraste entre medios). In C. Fuentes Rodríguez (Ed.), Imagen social y medios de comunicación, (pp. 95-120), Madrid: Arco Libros.

Greatbatch, D. (1992). On the management of disagreement between news interviews. In P. Drew \& J. Heritage (Eds.), Talk at work: Interaction in Institutional Settings (pp. 95-117). Cambridge: Cambridge University Press.

Haverkate, H. (1994). La cortesía verbal. Estudio pragmalingüístico. Madrid: Gredos.

Haverkate, H. (1998). La entrevista periodística. Análisis discursivo e interaccional. Oralia, 1, 27-45.

Heritage, J. (1985). Analyzing News Interviews: Aspects of the Production of Talk for an "Overhearing" Audience. In T. Van Dijk (Ed.) Handbook of Discourse Analysis, Vol.3, Discourse and Dialogue (pp. 95-117). London: Academic Press.

Holmes, J., \& Schnurr, S. (2005). Politeness, humor and gender in the workplace: negotiating norms and identifying contestation. Journal of Politeness Research, 1(1), 121-149. https://doi.org/10.1515/jplr.2005.1.1.121

Ilie, C. (2004). Insulting as (un)parliamentary practice in the British and Swedish parliaments. In P. Bayley (Ed.) Cross-Cultural Perspectives on Parliamentary Discourse (pp.46-86). Amsterdam: John Benjamins. https://doi.org/10.1075/dapsac.10.02ili

Joseph, J. (2004). Language and Identity: National, Ethnic, Religious. New York: Palgrave Macmillan. https://doi.org/10.1057/9780230503427

Lakoff, R. (1989). The limits of politeness: therapeutic and courtroom discourse. Multilingua, 8(2/3), 101-129. https://doi.org/10.1515/mult.1989.8.2-3.101

Lo Cascio, V. (1998). Gramática de la argumentación. Madrid: Alianza.

Locher, M. A., \& Watts, R. (2005). Politeness theory and relational work. Journal of Politeness Research, 1(1), 9-33. https://doi.org/10.1515/jplr.2005.1.1.9 
Lorenzo-Dus, N. (2009). Television discourse. Analysing language in the media. Basingstoke: Palgrave Macmillan.

Lunginbühl, M. (2007). Conversational violence in political TV debates: Forms and functions. Journal of Pragmatics, 39(8), 1371- 1387. https://doi.org/10.1016/j.pragma.2007.04.003

Penman, R. (1990). Facework and politeness: Multiple goals in courtroom discourse. In K. Tracy \& N. Coupland (eds.), Multiple goals in discourse (pp. 15-37). Clevedon: Multilingual Matters. https://doi.org/10.1177/0261927x9091002

Placencia, M. E., \& Fuentes Rodríguez C. (2013). In between spectacle and political correctness: Vamos con todo ¿An ambivalent news/talk? Pragmatics, 23(1), 119-147. https://doi.org/10.1075/prag.23.1.06pla

Rasiah, P. (2010). A framework for the systematic analysis of evasion in parliamentary discourse. Journal of Pragmatics, 42, 664-680. https://doi.org/10.1016/j.pragma.2009.07.010

Schegloff, E. A. (1988/89). From Interviews to Confrontation: Observations on the Bush/Rather Encounter. Research on Language and Social Interaction, 22, 215-240. https://doi.org/10.1080/08351818809389304

Schneider, K. P., \& Barron, A. (2008). Where pragmatics and dialectology meet: Introducing variational pragmatics. In K. P. Schneider \& A. Barron (eds.), Variational pragmatics: A focus on regional varieties in pluricentric languages (pp. 1-32). Amsterdam: John Benjamins. https://doi.org/10.1075/pbns.178.02sch

Simon, B. (2004). Identity in Modern Society. A Social Psychological Perspective. Oxford: Blackwell. https://doi.org/10.1002/9780470773437

Spencer-Oatey, H. (2007). Theories of identity and the analysis of face. Journal of Pragmatics, 39(4), 639-656. https://doi.org/10.1016/j.pragma.2006.12.004

Van Dijk, T. A. (2002). Political Discourse and Political Cognition. In P. Chilton \& C. Schaffner (Eds.) Politics as Text and Talk. Analytic Approaches to Political Discourse (pp. 203-239). Amsterdam/ Philadelphia: John Benjamins. https://doi.org/10.1075/dapsac.4.11dij

Watts, R. (2003). Politeness. Cambridge: Cambridge University Press. https://doi.org/10.1017/CBO9780511615184

\section{Notes}

Note 1. The recording lasts nine hours.

Note 2. As has been shown in Brenes Peña (2011) and Fuentes Rodríguez (ed. 2013a), verbal impoliteness as exhibited in recent years in various genres in Spanish television is on the increase. In general, the tendency is much more marked in talk shows, television discussion programs and interviews.

Note 3. This perspective has been presented in numerous papers, such as Fuentes Rodríguez (2010a) and edited volumes on impoliteness strategies in the media (Fuentes Rodríguez ed. 2013a, 2013b).

Note 4. For the distinction between social identity and face, see Fuentes Rodríguez (2013a), and for the definition of the features which determine identity see Bucholtz and Hall (2005), Joseph 2004 and Simon (2004).

Note 5. IE: Interviewee, IR: Interviewer.

Note 6. There are genres in which impoliteness plays no part. Purely informative formats such as news programs, where interaction between journalists is minimal, are unlikely to accommodate impoliteness.

Note 7. On the whole, the ideology staunchly defended by these programs in US television channels is a conservative one.

Note 8. This alteration of the speaking turns is the factor that most clearly shows how the rules for this communicative genre are ignored in the interview with President Bush analyzed by E. A. Schegloff (1988/89).

Note 9. For this reason, in the opinion of Blum Kulka (1983,147-149), the IR's strategy to reorient the IE must be implemented tactfully in order not to threaten his/her public face. The IR must refrain from openly and unmitigatedly questioning the adequacy of the answers offered by the IEs. The same opinion is held by Cortés \& Bañón (1997, 49), who observe how, when the IE does not answer, the IR "lets him know about this circumstance, but in a softened way".

Note 10. See Ekström-Patrona (2011), who denounces this lack of neutrality.

\section{Copyrights}

Copyright for this article is retained by the author(s), with first publication rights granted to the journal.

This is an open-access article distributed under the terms and conditions of the Creative Commons Attribution license which permits unrestricted use, distribution, and reproduction in any medium, provided the original work is properly cited. 